\title{
PROSEDUR AUDIT MANAJEMEN
}

\section{Rahmad Setyo Adi 165100111}

Fakultas Komputer

rahmadsetyoadi.student@umitra.ac.id

\begin{abstract}
Pengertian audit manajemen adalah tindakan kegiatan evaluasi semua kegiatan departemen perusahaan dengan maksud untuk memberikan saran yang tepat kepada manajemen. Dengan kata lain. Audit manajemen adalah tugas yang berorientasi pada masa depan dengan mengevaluasi semua tingkatan manajemen usaha secara tepat waktu seperti manajemen produksi. Manajemen penjualan DLL. Tujuan audit manajemen adalah untuk meningkatkan kapasitas keuntungan produksi perusahaan. Tujuan social perusahaan dan pengembangan sumber daya manusia sehingga tujuan organisasi dapat dicapai dengan mudah.
\end{abstract}

Kata Kunci : Manajemen audit 
A. PENDAHULUAN

Pengertian audit manajemen adalah tindakan kegiatan evaluasi semua kegiatan departemen perusahaan dengan maksud untuk memberikan saran yang tepat kepada manajemen

\section{B. PEMBAHASAN / STUDI KASUS}

Tujuan audit manajemen adalah untuk meningkatkan kapasitas keuntungan produksi perusahaan

\section{ID SECURITY}

QWTD4452377-ASP-5244107

\section{KESIMPULAN}

Audit dilakukan untuk analisis dan mengetahui keamanan dan integritas data dari system informasi yang digunakan, karena domain ini mencakup pengelolaan kelancaran dan keamanan sistem serta pengelolaan data dan operasional fasilitas.

\section{E. DISKUSI}

Saya bersama teman saya bernama Ahmad Yudi mendiskusikan tentang tahaptahap audit sistem informasi Hasil diskusi dari materi ini adalah Perangkat lunak yang digunakan oleh perusahaan adalah M-Care Sitem dan ESA Sistem. Audit dilakukan untuk analisis dan mengetahui keamanan dan integritas data dari system informasi yang digunakan. Audit menggunakan framework COBIT 4.1 . Domain yang digunakan adalah Delivery Support (DS), karena domain ini mencakup pengelolaan kelancaran dan keamanan system serta pengelolaan data dan operasional fasilitas.

\section{F. REFERENCE}

[1] O. M. Febriani and A. S. Putra, "Sistem Informasi Monitoring Inventori Barang Pada Balai Riset Standardisasi Industri Bandar Lampung," J. Inform., vol. 13, no. 1, pp. 90-98, 2014.

[2] A. S. Putra, "Paperplain: Execution Fundamental Create Application With Borland 
Delphi 7.0 University Of Mitra Indonesia," 2018.

[3] A. S. Putra, "2018 Artikel Struktur Data, Audit Dan Jaringan Komputer," 2018.

[4] A. S. Putra, "ALIAS MANAGER USED IN DATABASE DESKTOP STUDI CASE DB DEMOS."

A. S. Putra, "COMPREHENSIVE SET OF PROFESSIONAL FOR DISTRIBUTE COMPUTING."

[6] A. S. Putra, "DATA ORIENTED RECOGNITION IN BORLAND DELPHI 7.0."

[7] A. S. Putra, "EMBARCADERO DELPHI XE 2 IN GPUPOWERED FIREMONKEY APPLICATION."

[8] A. S. Putra, "HAK ATAS KEKAYAAN INTELEKTUAL DALAM DUNIA TEKNOLOGY BERBASIS REVOLUSI INDUSTRI 4.0."

[9] A. S. Putra, "IMPLEMENTASI PERATURAN

PERUNDANGAN UU. NO 31

TAHUN 2000 TENTANG DESAIN INDUSTRI BERBASIS INFORMATION TECHNOLOGY."

[10] A. S. Putra, "IMPLEMENTATION OF PARADOX DBASE." A. S. Putra, "IMPLEMENTATION OF TRADE SECRET CASE STUDY SAMSUNG MOBILE PHONE."

[12] A. S. Putra, "IMPLEMENTATION

PATENT FOR APPLICATION WEB BASED CASE STUDI WWW. PUBLIKLAMPUNG.
COM."

[13] A. S. Putra, "IMPLEMENTATION SYSTEM FIRST TO INVENT IN DIGITALLY INDUSTRY."

[14] A. S. Putra, "MANUAL REPORT \& INTEGRATED DEVELOPMENT ENVIRONMENT BORLAND DELPHI 7.0."

[15] A. S. Putra, "PATENT AS RELEVAN "SUPPORT RESEARCH."

[16] A. S. Putra, "PATENT FOR RESEARCH STUDY CASE OF APPLE. Inc."

[17] A. S. Putra, "PATENT PROTECTION FOR APPLICATION INVENT."

[18] A. S. Putra, "QUICK REPORT IN PROPERTY PROGRAMMING."

[19] A. S. Putra, "REVIEW CIRCUIT LAYOUT COMPONENT

REQUIREMENT ON ASUS NOTEBOOK."

[20] A. S. Putra, "REVIEW TRADEMARK PATENT FOR INDUSTRIAL TECHNOLOGY BASED 4.0."

[21] A. S. Putra, "TOOLBAR COMPONENT PALLETTE IN OBJECT ORIENTED PROGRAMMING."

[22] A. S. Putra, "WORKING DIRECTORY SET FOR PARADOX 7."

[23] A. S. Putra, "ZQUERY CONNECTION

IMPLEMENTED

PROGRAMMING STUDI CASE PT. BANK BCA Tbk."

[24] A. S. Putra, D. R. Aryanti, and I. Hartati, "Metode SAW 
(Simple Additive Weighting) sebagai Sistem Pendukung Keputusan Guru Berprestasi (Studi Kasus: SMK Global Surya)," in Prosiding Seminar Nasional Darmajaya, 2018, vol. 1, no. 1, pp. 85-97.

[25] A. S. Putra and O. M. Febriani, "Knowledge Management Online Application in PDAM Lampung Province," in Prosiding International conference on Information Technology and Business (ICITB), 2018, pp. 181-187.

[26] A. S. Putra, O. M. Febriani, and B. Bachry, "Implementasi Genetic Fuzzy System Untuk Mengidentifikasi Hasil Curian Kendaraan Bermotor Di Polda Lampung," SIMADA (Jurnal Sist. Inf. dan Manaj. Basis Data), vol. 1, no. 1, pp. 21-30, 2018.

[27] A. S. Putra, H. Sukri, and K. Zuhri, "Sistem Monitoring Realtime Jaringan Irigasi Desa (JIDES) Dengan Konsep Jaringan Sensor Nirkabel," IJEIS (Indonesian J. Electron. Instrum. Syst., vol. 8, no. 2, pp. 221-232.

[28] D. P. Sari, O. M. Febriani, and A. S. Putra, "Perancangan Sistem Informasi SDM Berprestasi pada SD Global Surya," in Prosiding Seminar Nasional Darmajaya, 2018, vol. 1, no. 1, pp. 289-294. 